\begin{tabular}{|l|l|l||}
\hline \multicolumn{2}{|c|}{ PublisherInfo } \\
\hline \hline PublisherName & $:$ & BioMed Central \\
\hline \hline PublisherLocation & $:$ & London \\
\hline \hline PublisherImprintName & $:$ & BioMed Central \\
\hline \hline
\end{tabular}

\title{
Counting tillers
}

\begin{tabular}{|l|l|l||}
\hline \multicolumn{2}{|c|}{ ArticleInfo } \\
\hline \hline ArticleID & $:$ & 4746 \\
\hline \hline ArticleDOI & $:$ & $10.1186 /$ gb-spotlight-20030410-02 \\
\hline \hline ArticleCitationID & $:$ & spotlight-20030410-02 \\
\hline \hline ArticleSequenceNumber & $:$ & 98 \\
\hline \hline ArticleCategory & $:$ & Research news \\
\hline ArticleFirstPage & $:$ & 1 \\
\hline \hline ArticleLastPage & $:$ & 2 \\
\hline \hline & & RegistrationDate : 2003-4-10 \\
\hline ArticleHistory & $:$ & OnlineDate \\
\hline \hline ArticleCopyright & $:$ & BioMed Central Ltd2003-10 \\
\hline \hline ArticleGrants & $:$ & \\
\hline \hline ArticleContext & $:$ & 130594411 \\
\hline \hline
\end{tabular}




\section{Andrea Rinaldi}

Email: rinaldi@unica.it

Rice is the staple food crop for the majority of the world's population, making it crucial to understand the mechanisms that govern its growth and productivity. At maturity the rice plant has a main stem and a number of grain-bearing tillers, and it is the number of these tillers that determines grain yield. The molecular processes that control rice tillering have been poorly understood. In the April 10 issue of Nature, Xueyong Li and colleagues at the Chinese Academy of Sciences, Beijing, China, report the isolation and characterization of a gene that regulates rice branching (Nature 2003, 422:618-620).

Li et al. screened rice plant collections for mutants with altered tiller numbers. Genetic analysis with reciprocal crosses between tiller mutants and wild-type plants revealed that mutants possess a recessive mutation in a single locus, termed Monoculm 1 (MOC1). The $M O C 1$ gene was then mapped to the long arm of chromosome 6 , and encoded a nuclear-localized protein of 441 amino-acid residues. Tiller mutants transformed with up to three copies of the $M O C 1$ gene produced 2-3 fold more tillers than wildtype plants, confirming the role of the gene in branching control. High-tillering transformed plants were also observed to be shorter than wild-type plants, indicating that $M O C 1$ affects both rice tillering and plant height - another economically important trait.

Although $\mathrm{MOCl}$ seems to be a key regulator of rice tillering, this is expected to be a complex process which involves the finely-tuned expression of many genes. The identification of the other parties is likely to benefit from the recent completion of several drafts of the rice genome, produced by the International Rice Genome Sequencing Project and other sequencing programs.

\section{References}

1. Nature, [http://www.nature.com]

2. Chinese Academy of Sciences, [http://www.cas.ac.cn/english]

3. Towards an accurate sequence of the rice genome.

4. International Rice Genome Sequencing Project, [http://rgp.dna.affrc.go.jp/IRGSP/] 